16,13

\title{
Исследование пиролизата фталоцианина Fe методами мессбауэровской спектроскопии и просвечивающей электронной микроскопии
}

\author{
(C) В.С. Козлов ${ }^{1}$, В.Г. Семенов ${ }^{1,2}$, К.Г. Каратеева ${ }^{3}$, В.Ю. Байрамуков ${ }^{1, \uparrow}$ \\ ${ }^{1}$ Петербургский институт ядерной физики им. Б.П. Константинова \\ Национального исследовательского центра „Курчатовский институт“, \\ Гатчина, Россия \\ ${ }^{2}$ Санкт-Петербургский государственный университет, Институт химии, \\ Петергоф, Россия \\ ${ }^{3}$ Национальный исследовательский центр „Курчатовский институт“, \\ Москва, Россия \\ ฯ E-mail: vbayramukov@gmail.com \\ (Поступила в Редакцию 1 ноября 2017 г. \\ В окончательной редакции 21 ноября 2017 г.)
}

\begin{abstract}
Методами мессбауэровской спектроскопии и просвечивающей электронной микроскопии проведено исследование пиролизата фталоцианина железа, определен фазовый состав и магнитное состояние продуктов пиролиза, представленных фазами $\alpha$ - $\mathrm{Fe}, \gamma$ - $\mathrm{Fe}, \mathrm{Fe}_{3} \mathrm{C}$ и магнетитом. Определены морфологические особенности углеродных и железосодержащих фаз, представленных металлическими частицами разнообразной формы и размеров, а также углеродными нанотрубками, углеродными полыми нанополиэдрами и неграфитизированным углеродом. Проведен сравнительный анализ морфологии и структуры пиролизатов фталоцианина железа и дифталоцианинов редкоземельных элементов.
\end{abstract}

Мессбауэровские исследования и просвечивающая электронная микроскопия выполнены с использованием оборудования Института химии СПбГУ и Ресурсного центра зондовой и электронной микроскопии „Нанозонд“ Курчатовского комплекса НБИКС-технологий НИЦ КИ.

DOI: 10.21883/FTT.2018.05.45806.307

\section{1. Введение}

Изучение пиролизатов моно- и дифталоцианинов ряда переходных и редкоземельных элементов (Р3Э) представляет значительный научный и практический интерес для получения новых наноструктурированных металлоуглеродных материалов, таких как углеродные нанотрубки (УНТ), нанокабели, наностержни [1,2], графитизированные капсулы, углеродные волокна и т.д. [3], а также для создания термически, химически и радиационностойких металлоуглеродных матриц для хранения радиоактивных отходов [4].

Однако к настоящему времени имеются противоречивые результаты по изучению экспериментальными методами продуктов пиролиза, полученных при различных физико-химических условиях.

Пиролизаты монофталоцианинов переходных элементов (в частности, Fe) особенно важны как специальные молекулярные прекурсоры для направленного синтеза новых эндометаллофуллеренов (ЭМФ), инкапсулирующих атомы $3 d$-элементов [5] и представляющих особый интерес из-за их магнитных свойств. Разработка эффективного способа получения ЭМФ Fе позволила бы существенно расширить круг наноматериалов для биомедицинских применений (контрастирующие агенты для МРТ-диагностики, фототермическая терапия и т.д.).
Авторы работы [2] пиролизом монофталоцианинов $\mathrm{Fe}$ $(\mathrm{FePc})$ и $\mathrm{Co}(\mathrm{CoPc})$ в температурном диапазоне от 600 до $1000^{\circ} \mathrm{C}$ получили УНТ различной морфологии и состава в виде металлических сердечников в углеродной оболочке длиной до $10 \mu \mathrm{m}$ (нанокабели) или многостенных УНТ с карбидом Fе внутри. Их морфология зависела от состава прекурсоров (фталоцианинов металлов) и температурных условий пиролиза. Предварительное измельчение в шаровой мельнице влияло на температуру возгонки паров FePc, и в итоге - на диаметр УНТ [6]. Пиролиз FePc в присутствии тиола в атмосфере $\mathrm{Ar} / \mathrm{H}_{2}$ при $800 \sim 900^{\circ} \mathrm{C}$ приводил к образованию многостенных разветвленных нанотрубок благодаря находящимся внутри УНТ частицам Fe, служившим центрами нуклеации УНТ [7]. В работе [8] карбид железа, инкапсулированный в углеродную оболочку, синтезировали пиролизом FePc в потоке $\mathrm{H}_{2}$ при $300-400^{\circ} \mathrm{C}$. Полученные нанокапсулы имели структуру типа усов с размерами $500 \times 100 \mathrm{~nm}$, при толщине углеродной оболочки около $\sim 2.7 \mathrm{~nm}$. При повышении температуры пиролиза металлическое железо было основным инкапсулированным продуктом. Пиролиз металлорганического прекурсора при прокаливании в инертной атмосфере [9] или с использованием лазерного способа пиролиза $[10,11]$ приводил к образованию „луковичных“ („ядро-оболочка“) структур. 
Представленный обзор демонстрирует разнообразие инкапсулированных в углеродную оболочку железосодержащих структур, которые можно получить пиролизом таких прекурсоров, как металлофталоцианины $(\mathrm{MePc})$, причем конечный тип структур существенно зависит от температурных условий, состава прекурсора и атмосферы проведения пиролиза. Перечисленные моменты предопределили направление данной работы.

Основной целью данной работы было исследование фазового состава, морфологии, магнитного состояния, размеров образующихся наночастиц в продуктах пиролиза $\mathrm{FePc}$ и сравнение результатов с раннее полученными данными по пиролизу дифталоцианинов РЗЭ. Для успешного выполнения поставленной цели мы выбрали следующие экспериментальные методы: мессбауэровская спектроскопия (МС), являющаяся в данном случае наиболее информативным методом определения фазового состава железосодержащих фаз, а также возможной локальной неоднородности в окружении атомов железа $[12,13]$ и просвечивающая электронная микроскопия (ПЭМ), обеспечивающая визуализацию исследуемых образцов.

\section{2. Экспериментальная часть}

Пиролизат FePc получали нагреванием порошка фталоцианина железа при температуре $700-800^{\circ} \mathrm{C}$ в токе инертного газа и последующим отжигом при температуре $\sim 1100^{\circ} \mathrm{C}$ в течение $1.5-2 \mathrm{~h}$ [14]. Мессбауэровские спектры снимались на спектрометре электродинамического типа в режиме постоянного ускорения с источником ${ }^{57} \mathrm{Co}(\mathrm{Rh})$ при $300 \mathrm{~K}$. Калибровка скоростей и химический сдвиг даны относительно общепринятого стандарта $\alpha$-Fе. Мессбауэровские спектры обрабатывали в программе MOSSFIT в предположении лоренцевой формы линии.

Морфологию и структуру образцов изучали с помощью просвечивающего электронного микроскопа TITAN 80-300, снабженного энергодисперсионным рентгеновским спектрометром (ЭДРС), позволяющим определять химический состав с атомарным разрешением. Исследуемый образец смешивали со спиртом и подвергали воздействию ультразвука в течение $25 \mathrm{~min}$, затем с помощью дозатора каплю суспензии наносили на углеродную сетку (Lacey Carbon), выполняющую роль подложки.

\section{3. Результаты и обсуждение}

В связи с обсуждаемыми ниже результатами следует сначала привести характерные данные по определению структурного и фазового состава железосодержащих нанокластеров с помощью МС на ядрах ${ }^{57} \mathrm{Fe}$. Как известно, мессбауэровский спектр FePc (рис. 1,a) состоит из двух дублетов, отвечающих степени окисления $\mathrm{Fe}^{2+}$ и $\mathrm{Fe}^{3+}$ в $\beta$-полиморфе FePc [15].
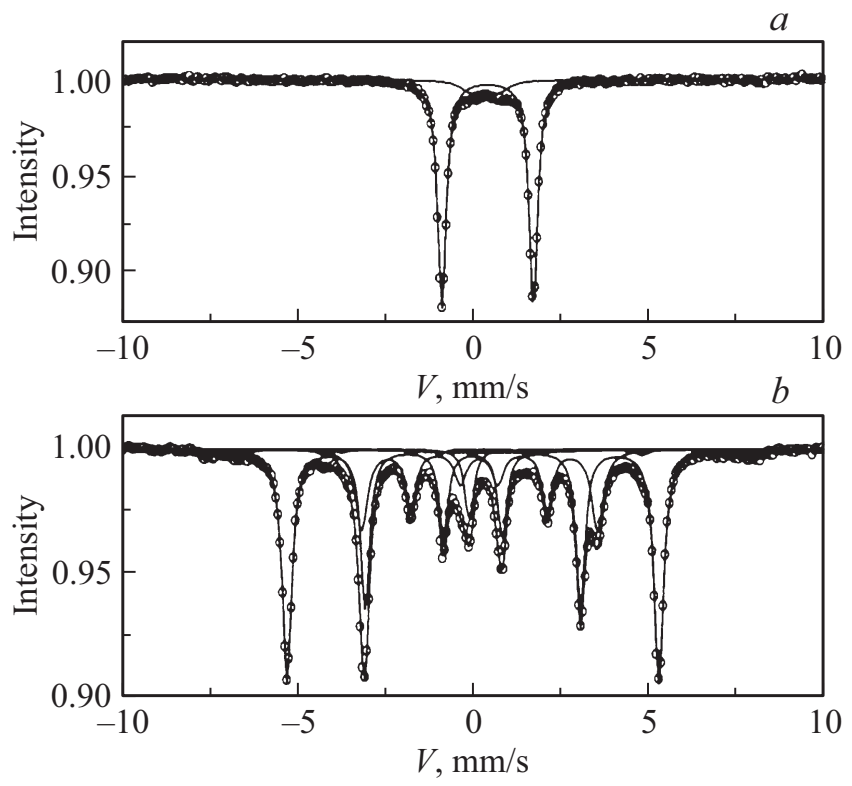

Рис. 1. Мессбауэровские спектры: $a-\mathrm{FePc} ; b-$ пиролизата FePc.

Пиролиз FePc при указанных выше условиях приводит к усложнению спектра (рис. 1,b), который состоит из одного синглета и четырех секстетов с параметрами, основным из которых для идентификации секстета с соответствующей $\mathrm{Fe}-$ содержащей фазой является величина

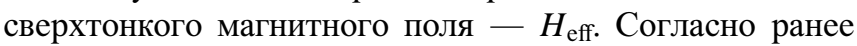
опубликованным данным [16], пиролизат FePc состоит из нескольких железосодержащих фаз: $\alpha$-Fe, $\gamma$-Fe, $\mathrm{Fe}_{3} \mathrm{C}$, а также двух фаз магнетита $\left(\mathrm{Fe}_{2} \mathrm{O}_{3}\right)$, доля которого не превышает 9\% (см. таблицу).

По-видимому, указанные железосодержащие фазы, как было показано выше, могут быть инкорпорированы в УНТ, а также формировать структуры типа „ядрооболочка“, нанокабели, наностержни и другие виды нанообъектов. Использование ПЭМ позволило нам изучить морфологию, структуру и состав пиролизата FePc и сопоставить полученные данные с данными мессбауэровской спектроскопии.

ПЭМ-изображение пиролизата $\mathrm{FePc}$ в светлопольном режиме представлено на рис. 2. Отчетливо видны металлические частицы разнообразной формы и размеров $(10-100 \mathrm{~nm})$, находящиеся на поверхности углеродной матрицы.

Изображение в темнопольном режиме (рис. 3) позволяет однозначно проявлять металлические частицы в виде ярких пятен на темном фоне углеродной матрицы. В спектрах ЭДРС пиролизата $\mathrm{FePc}$ в точках 1 и 2 (рис. $4, a, b)$ доминируют рентгеновские линии Fе при практическом отсутствии линий углерода и кислорода, что свидетельствует о металлической фазе железа, которая, по данным мессбауэровской спектроскопии (см. таблицу), является фазой $\alpha$-Fe. В точках 3 и 4 (рис. $4, c, d)$ наблюдается иной спектр рентгеновских линий, характерный для чисто углеродной фазы матрицы 
Сверхтонкие параметры мессбауэровских спектров FePc и пиролизата FePc при $300 \mathrm{~K}$

\begin{tabular}{c|c|c|c|c|c|c|c}
\hline Образец & Субспектр & $W^{a}, \mathrm{~mm} / \mathrm{s}$ & $I S^{a}, \mathrm{~mm} / \mathrm{s}$ & $Q S^{a}, \mathrm{~mm} / \mathrm{s}$ & $H_{\text {eff, }}^{b}$ & $S^{c}, \%$ & $\Phi$ aза \\
\hline \multirow{2}{*}{ FePc } & Дублет-1 & 0.29 & 0.38 & 2.61 & - & 88 & $\mathrm{Fe}^{2+}$ \\
& Дублет-2 & 0.75 & 0.29 & 0.78 & - & 12 & $\mathrm{Fe}^{3+}$ \\
\hline \multirow{3}{*}{ Пиролизат } & Синглет-1 & 0.30 & -0.10 & - & - & 4 & $\gamma$-Fe \\
FеРс & Секстет-1 & 0.30 & 0 & - & 33.0 & 60 & $\alpha$-Fe \\
& Секстет-2 & 0.37 & 0.18 & -0.01 & 21.0 & 27 & $\mathrm{Fe}_{3} \mathrm{C}$ \\
& Секстет-3 & 0.36 & 0.27 & 0.04 & 48.6 & 3 & $\mathrm{Fe}_{3} \mathrm{O}_{4}$
\end{tabular}

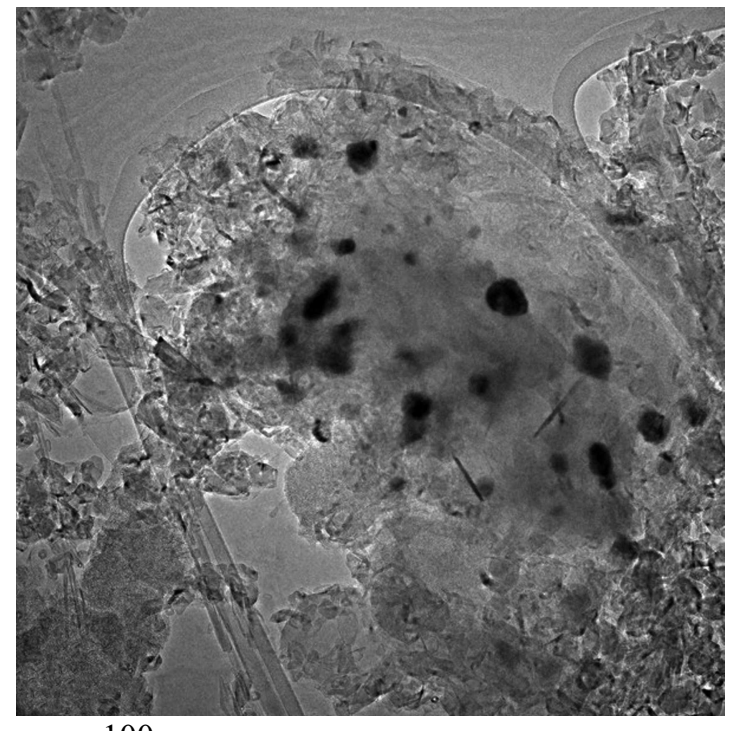

$100 \mathrm{~nm}$

Рис. 2. ПЭМ-изображение пиролизата $\mathrm{FePc}$ (светлопольный режим).

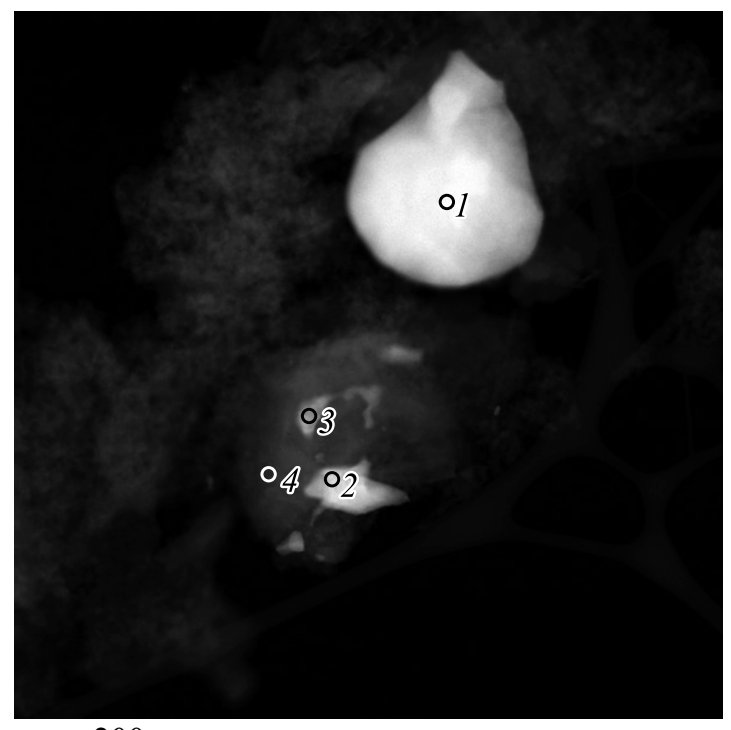

$200 \mathrm{~nm}$

Рис. 3. ПЭМ-изображение пиролизата $\mathrm{FePc}$ (точки 1-4) (темнопольный режим). и фазы металлического железа, находящегося в объеме углеродной матрицы, соответственно.

Для уточнения фазового состава пиролизата методом Лауэ была получена картина электроннодифракционного рассеяния на образце (рис. 5, $a$ ). Моделирование (рис. $5, b$ ), путем сравнения дифракционных картин от разных фаз, позволило идентифицировать в пиролизате преобладающие фазы графита, карбида железа и $\alpha$-Fe при незначительном проявлении фазы $\gamma$-Fe и отсутствии фазы магнетита в пределах экспериментальной точности.

Анализируя ПЭМ-изображения пиролизата FePc, удалось идентифицировать металлические наностержни (рис. 6), углеродные пустотелые нанополиэдры, углеродные нанотрубки, а также углеродную матрицу, которая, по данным авторов [17], представляет собой структуру неграфитизированного углерода на основе фуллереноподобных (сажевых) элементов (рис. 7). Не были обнаружены структуры типа ядро-оболочка или заполненные металлом УНТ.

Следует отметить, что несколько иные результаты были получены в работе [2]. Пиролиз $\mathrm{FePc}$, проведенный при $800^{\circ} \mathrm{C}$ в вакуумированной ампуле со скоростью нагревания $20^{\circ} \mathrm{C} / \mathrm{min}$, приводил к образованию металлических частиц микронного размера и формированию УНТ, заполненных карбидом железа.

Таким образом, выбор условий пиролиза (температуры, скорости нагрева, времени выдержки при данной температуре, вакуумирования или тока инертного газа и т.д.) позволяет получать контролируемым способом наноструктуры различной морфологии и состава.

Результаты проведенного нами пиролиза FePc сравнивались с данными для пиролизатов дифталоцианинов Р3Э $\left(\mathrm{MePc}_{2}\right)$. Пиролиз $\mathrm{MePc}_{2}$ при $T=800-900^{\circ} \mathrm{C}$ вызывал деструкцию дифталоцианина с выделением газообразных продуктов, и, как предполагалось, в молекулах лиганды соединялись крайними атомами углерода через освободившиеся связи в замкнутую углеродную ячейку с атомом металла внутри $[4,18,19]$. В результате образуется пористая углеродная структура [20], строение которой на масштабах $10-10^{2} \mathrm{~nm}$ характеризуется двумя уровнями - малыми порами с характерными радиусами 3-7 nm, формирующими агрегаты размера- 

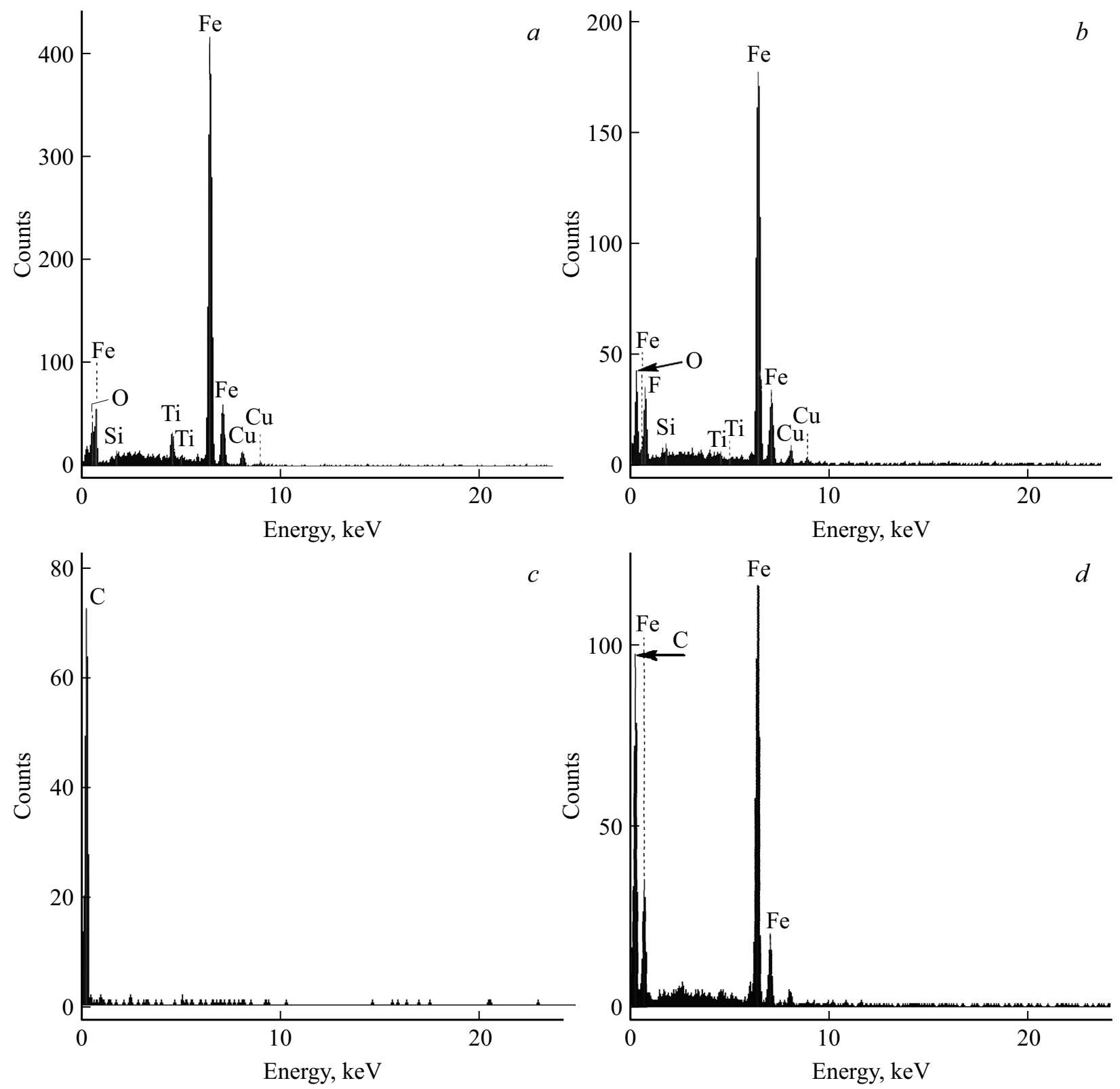

Рис. 4. $(a, b, c, d)$ ЭДРС-спектры точек $(1-4)$ на рис. 3 соответственно.

ми 40-100 nm и выше. Результаты измерений атомносиловой микроскопии [21] подтвердили гипотезу об образовании в процессе пиролиза $\mathrm{MePc}_{2}$ разветвленной сети нанокластеров с размерами 5-150 nm. Образование при пиролизе $\mathrm{MePc}_{2}$ замкнутых структур, кроме научного, имеет практическое значение для создания более эффективного (по сравнению с пиролизатом МеРс) прекурсора в целях направленного и производительного синтеза ЭМФ РЗЭ.

Моно- и дикомплексы МеРс и МеРс 2 обладают разной структурой, поэтому их пиролизаты также будут иметь различные свойства, что подтверждается данными работы [22]. Температурная стабильность на примере $\mathrm{EuPc}$ и $\mathrm{EuPc}_{2}$ изучена методом термогравиметрического анализа в диапазоне температур до $1000^{\circ} \mathrm{C}$ в атмосфере аргона [23]. Установлено, что потери массы для $\mathrm{EuPc}_{2}$ к $851^{\circ} \mathrm{C}$ достигают 93\%, а для $\mathrm{EuPc}_{2}$ к $1000^{\circ} \mathrm{C}$ составляют лишь $67 \%$, что свидетельствует о большей термостойкости последнего. Кроме того, показана высокая термическая устойчивость комплексов лантаноидов по сравнению с фталоцианинами переходных элементов.

Структура аморфной фазы пиролизатов дифталоцианина лантана, по данным рассеяния рентгеновских лучей, представлена в работе [24]. Показано, что при температуре отжига до $1000^{\circ} \mathrm{C}$ происходит интенсивная интеграция углерода в глобулы размером $\sim 1 \mathrm{~nm} \mathrm{c}$ числом атомов $m \geq 100$, стабильные по размерам и массе в диапазоне $1000-1600^{\circ} \mathrm{C}$ и приближающиеся по плотности к графиту. Установлено, что в аморфной фазе пиролизатов, полученных в широком диапазоне 
температур $\left(800-1800^{\circ} \mathrm{C}\right)$, не выявлена сегрегация лантана, т.е. он заключен в аморфную углеродную матрицу наноглобулярной морфологии преимущественно в атомарном виде. Аналогичные результаты были получены в работе [25]. Авторам удалось идентифицировать фазу кристаллизованных нитридов и карбидов РЗЭ, величина кристаллитов которых растет с температурой и временем отжига от единиц нанометров до сотни.

Сопоставляя наши экспериментальные данные по пиролизатам FePc с приведенными выше данными по пиролизатам $\mathrm{MePc}_{2}$, можно обнаружить некоторое сходство и различие в морфологии углеродных нанокластеров, структуре и фазовом составе продуктов пиролиза.

Пиролиз $\mathrm{FePc}$ и $\mathrm{MePc}_{2}$ в близких физико-химических условиях приводит к образованию фазы аморфного углерода, карбидов железа или РЗЭ и фазы графита, кристалличность которой возрастает с ростом температуры и времени отжига. Важным отличием являет-
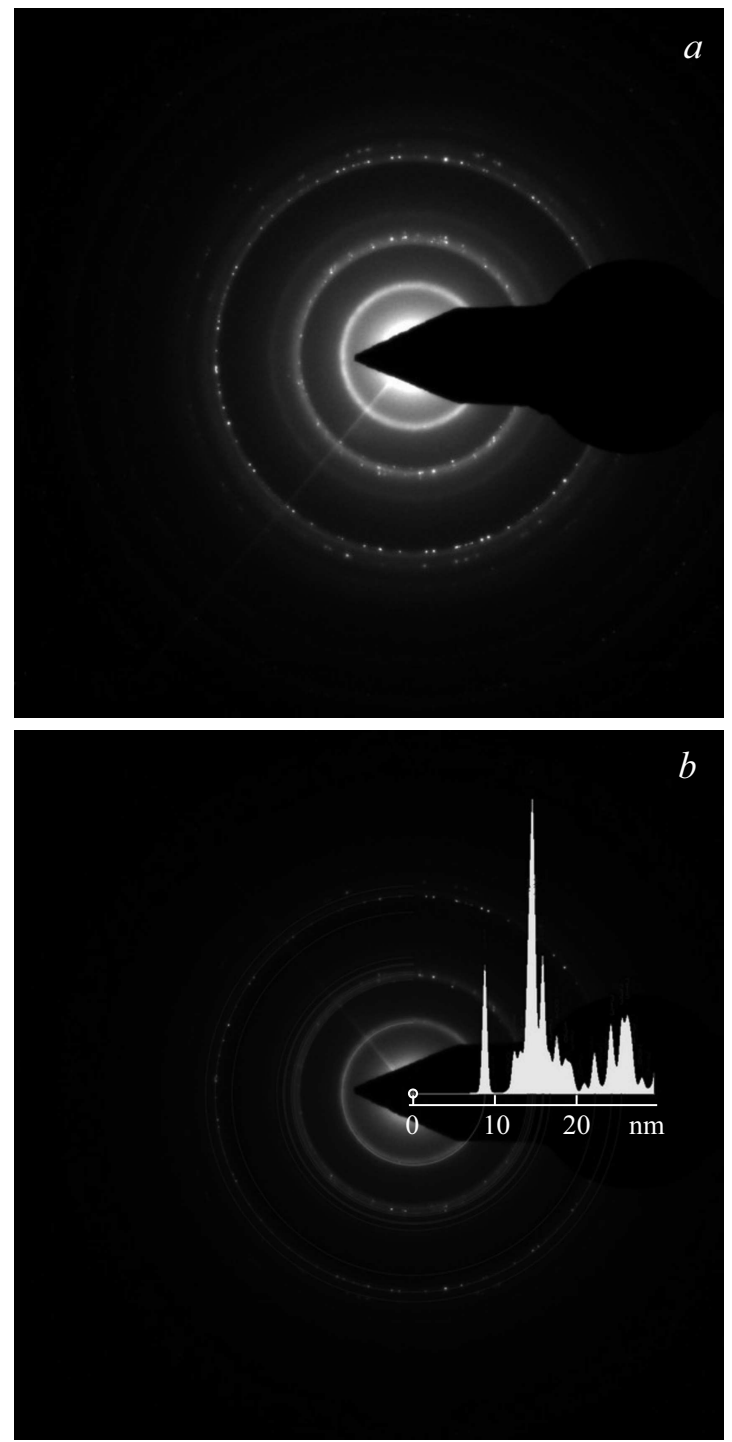

Рис. 5. $a-$ лауэграмма пиролизата FePc; $b-$ наложение фаз графита и карбида Fe.

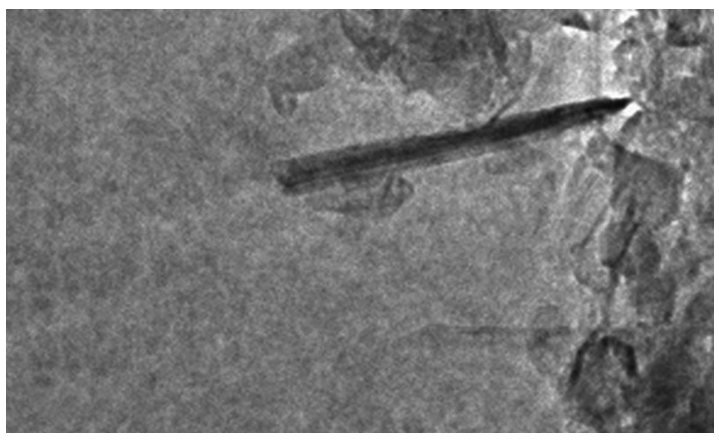

$50 \mathrm{~nm}$

Рис. 6. ПЭМ-изображение металлического наностержня (светлопольный режим).

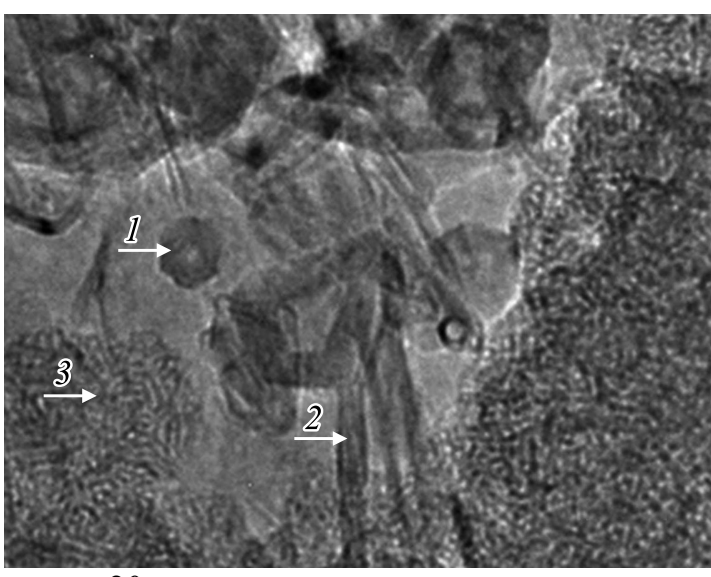

$20 \mathrm{~nm}$

Рис. 7. ПЭМ-изображение пиролизата $\mathrm{FePc}$ (светлопольный режим). 1 - углеродные пустотелые нанополиэдры, 2 - углеродные нанотрубки, 3 - неграфитизированный углерод.

ся равномерное распределение металла в пиролизате $\mathrm{MePc}_{2}$ [25], тогда как в пиролизате $\mathrm{FePc}$ образуются отдельные кластеры $\alpha$-Fe, металлические наностержни и фаза магнетита. Углеродная компонента представлена как кристаллическим, так и неграфитизированным сажевым углеродом, полыми нанополиэдрами и нанотрубками. Эти различия становятся более понятными с учетом следующих факторов.

Атомная доля лантана в пиролизате $\mathrm{MePc}_{2}$ составляет $\sim 3 \%$ [24] против 10\% в пиролизате FePc [5]. Известно, что $3 d$-металлы являются эффективными катализаторами образования УНТ, а молекула FePc при пиролизе как раз и является источником углерода и катализатора $(\mathrm{Fe})$, необходимого для роста УНТ. Избыток железа может образовывать металлические частицы размерами до $100 \mathrm{~nm}$ (см. рис. 2,3) с учетом склонности атомов $3 d$-металлов взаимодействовать друг с другом с формированием депозита из металлических нанокластеров [26,27]. Аналогичное образование металлических частиц наблюдали при электродуговом сжигании композитных электродов, содержащих пиролизат FePc [28]. 


\section{4. Заключение}

Методом МС изучены пиролизаты FePc, определен фазовый состав и магнитное состояние продуктов пиролиза, представленных железосодержащими фазами $\alpha$-Fe, $\gamma$ - $\mathrm{Fe}, \mathrm{Fe}_{3} \mathrm{C}$ и $\mathrm{Fe}_{2} \mathrm{O}_{3}$.

Использование ПЭМ позволило выявить особенности морфологии, определить состав и структуру углеродных и железосодержащих фаз, обнаружить металлические частицы $\alpha$-Fe, разнообразной формы и размеров, а также наностержни.

Методом электронной дифракции идентифицированы фазы карбида железа и $\gamma$-Fe. Показано, что углеродные структуры представлены углеродными нанотрубками, нанополиэдрами и матрицей из неграфитизированного рентгеноаморфного сажевого углерода.

Проведен сравнительный анализ морфологии и структурных особенностей пиролизатов фталоцианина железа и дифталоцианина РЗЭ. Определены сходства и различия в морфологии и составе полученных фаз.

Впервые показано, что пиролиз фталоцианинов железа ведет к образованию металлических нанокластеров размером до $100 \mathrm{~nm}$ в виде включений в углеродной матрице. Это является радикальным отличием от результатов пиролиза дифталоцианина, когда наблюдается равномерное распределение РЗЭ в матрице из углеродных глобул, инкапсулирующих атомы этих элементов.

Таким образом, строение исходной металлорганической молекулы предопределяет природу структурных превращений при пиролизе в зависимости от того, связан ли атом металла с одним лигандом, либо заключен между лигандами, образуя с ними координационные связи.

Авторы признательны В.Т. Лебедеву за полезные рекомендации и поддержку.

\section{Список литературы}

[1] L. Zhi, U. Kolb, K. Mullen. New carbon mater. 21, 2, 109 (2006).

[2] L. Zhi, T. Gorelik, R. Friedlein, J. Wu, U. Kolb, W.R. Salaneck, K. Müllen. Small 1, 8-9, 798 (2005).

[3] A.S. Manukyan, A.A. Mirzakhanyan, G.R. Badalyan, G.H. Shirinyan, A.G. Fedorenko, N.V. Lianguzov, Yu.I. Yuzyuk, L.A. Bugaev, E.G. Sharoyan. J. Nanopart. Res 14, 982 (2012).

[4] В.И. Тихонов, В.К. Капустин, В.Т. Лебедев, А.Е. Совестнов, В.Ю. Байрамуков, К.Я. Мишин. Радиохимия 58, 5, 469 (2016).

[5] В.П. Седов, А.А. Сжогина, В.Т. Лебедев. Новые эндометаллофуллерены, инкапсулирующие атомы железа. Препринт 2963 НИЦ КИ ПИЯФ (2014). 12 с.

[6] A.S. Milev, N. Tran, G.S. Kamali Kannangara, M.A. Wilson, I. Avramov. J. Phys. Chem. C 112, 5339 (2008).

[7] Q. Wei, Y. Liu, L. Zhang, S. Huang. Nano-Micro Lett. 5, 2, 124 (2013)

[8] N.S. Kopelev, V. Chechersky, A. Nath, Zh.L. Wang, E. Kuzmann, B. Zhang, G.H. Via. Chem. Mater. 7, 1419 (1996).
[9] B. An, K. Cheng, C. Wang, Y. Wang, W. Lin. ACS Catal. 6, 6, 3610 (2016).

[10] J. Sourice, A. Quinsac, Y. Leconte, O. Sublemontier, W. Porcher, C. Haon, A. Bordes, E. De Vito, A. Boulineau, S.J. Si Larbi, N. Herlin-Boime, C. Reynaud. Abstract LiBD-7 2015 - Electrode materials. Arcachon, France (June 21-26, 2015).

[11] C. Fleaca, F. Dumitrache, E. Dutu, C. Luculescu, A. Niculescu, A. Ilie, E. Vasile. U.P.B. Sci. Bull. B 78, 2, 1454 (2016).

[12] С.И. Бондаревский, В.В. Еремин, В.В. Панчук, В.Г. Семенов, М.Г. Осмоловский. ФТТ 58, 2, 77 (2016).

[13] A.C. Камзин, K.E. Ranjith, P. Ranjith, P. Ramadevi, C. Selvakumar. ФTT 59, 9, 1816 (2017).

[14] В.А. Шилин, С.Г. Колесник, Н.А. Куликова, В.В. Кукоренко, В.П. Седов, А.А. Сжогина, С.В. Фомин, Ю.Е. Логинов, А.А. Афанасьев. Разработка технологии производительного получения водорастворимых эндоэдральных металлофуллеренов. Ч. 2. Сообщение 2972. НИЦ КИ ПИЯФ (2015). $21 \mathrm{c}$.

[15] E. Kuzmann, Z. Homonnay, A. Vertes, S. Li, H. Ying, Y. Wei, A. Nath, X. Chen, J. Li. J. Solid State Chem. 170, 118 (2003).

[16] В.С. Козлов, В.Г. Семенов, В.В. Панчук. Электродуговой синтез Fе-углеродных нанокластеров. Ч. 1. Сообщение 2988. ПИЯФ НИЦ КИ (2016). 21 с.

[17] Peter J.F. Harris. J. Mater. Sci. 48, 565 (2013).

[18] V.I. Tikhonov, P.N. Moskalev, V.K. Kapustin. Proc. 11th Int. Conf. Environmental Remediation and Radioactive Waste Management ICEM-2007. Belgium. Report N 7084 (2008).

[19] В.И. Тихонов, В.К. Капустин, П.Н. Москалев. Пат. № 2343575 (РФ). Способ фиксации долгоживущих радионуклидов для хранения и трансмутации. ПИЯФ. 19.02.07.

[20] В.М. Лебедев, В.Т. Лебедев, Д.Н. Орлова, В.И. Тихонов. Поверхность. Рентген., синхротр. и нейтрон. исслед. 5, 5 (2014).

[21] V.Yu. Bairamukov, D.V. Lebedev, V.I. Tikhonov. Proc. Int. multidisciplinary microscopy congress. Antalya, Turkey. (October 10-13, 2013). Ser. Springer Proceedings in Physics (2014). Vol. 154. P. 189-195.

[22] А.В. Зиминов, С.М. Рамш, Т.А. Юрре. Тезисы Всероссийской научно-практической конференции студентов и аспирантов „Химия и химическая технология в XXI веке“(1415 мая 2007 г.), изд-во Томского политехнического ун-та, Томск (2007). $373 \mathrm{c}$.

[23] А.В. Зиминов, С.М. Рамш, И.Г. Спиридонов, Т.А. Юрре, Т.Г. Бутхузи, А.М. Туриев. Вестн. Санкт-Петербургского ун-та 4, 4, 95 (2009).

[24] В.Т. Лебедев, А.Е. Совестнов, В.И. Тихонов, Ю.П. Черненков. Поверхность. Рентген., синхротр. и нейтрон. исслед. 1, 25 (2017).

[25] А.Е. Совестнов, В.К. Капустин, В.И. Тихонов, Э.В. Фомин, Ю.П. Черненков. ФТТ 56, 8, 1621 (2014).

[26] В.В. Ивановская, А.Л. Ивановский. Успехи химии 80, 8, 761 (2011)

[27] Y. Zhang, Franklin, W. Nathan, R.J. Chen, H. Dai. Chem. Phys. Lett. 331, 1, 35 (2000).

[28] В.С. Козлов, О.А. Балабас, Е.В. Убыйвовк. Электродуговой синтез Fе-углеродных нанокластеров. Ч. 2. Сообщение 2997. ПИЯФ НИЦ КИ (2016). 19 с. 